\title{
Transplants of Immunologically Isolated Xenogeneic Chromaffin Cells Provide a Long-Term Source of Pain-reducing Neuroactive Substances
}

\author{
Jacqueline Sagen,' Hong Wang, ${ }^{1}$ Patrick A. Tresco, ${ }^{2}$ and Patrick Aebischer ${ }^{2}$ \\ ${ }^{1}$ Department of Anatomy and Cell Biology, University of Illinois at Chicago, Chicago, Illinois 60612 and ${ }^{2}$ Section for \\ Artificial Organs, Biomaterials and Cellular Technology, Brown University, Providence, Rhode Island 02912
}

\begin{abstract}
Adrenal medullary chromaffin cells are a potential source of neuroactive substances for transplantation into the CNS to alleviate neurochemical deficits. In particular, work in our laboratory has suggested that adrenal medullary transplants in the spinal subarachnoid space can alleviate pain by providing sustained local delivery of catecholamines and opioid peptides. One of the major limitations for clinical application of neural transplantation is the availability of donor material in sufficient quantities. This limitation may be overcome by the use of xenogeneic donors if long-term graft rejection can be prevented. The purpose of this study was to assess whether xenogeneic chromaffin cells immunologically isolated by semipermeable membranes could survive and continue to reduce pain when transplanted into the CNS. Isolated bovine chromatfin cells were encapsulated by semipermeable polymer membranes and implanted into the rat spinal subarachnoid space. Pain sensitivity was assessed at several intervals up to 3 months following implantation. Results indicated that encapsulated bovine chromaffin cell implants, but not empty control capsules, could repeatedly reduce pain sensitivity with nicotine stimulation for the duration of the study. This response was dose related, indicating that pharmacologic integrity of the transplanted chromaffin cells is retained. The analgesia induced by encapsulated chromaffin cell implants could be attenuated by the opiate antagonist naloxone and the $\alpha$-adrenergic antagonist phentolamine, suggesting the involvement of both opioid peptides and catecholamines in mediating this response. In addition, in vitro neurochemical studies of recultured capsules revealed sustained release of Met-enkephalin and catecholamines from encapsulated cells 3 months following implantation into the spinal subarachnoid space. The results of this study suggest that immunologically isolated xenogeneic cells can provide a long-term source of neuroactive substances for the alleviation of pain.
\end{abstract}

[Key words: adrenal medulla, neural transplants, analgesia, nociception, catecholamines, opioid peptides, encapsulation]

\footnotetext{
Received July 21, 1992; revised Dec. 1, 1992; accepted Dec. 8, 1992.

The technical expertise of Ms. Mary Lavallee in the execution of the neurochemical assays is greatly appreciated. This work was supported by NIH Grant NS25054. The animal studies were done in accordance with the guidelines for the care and use of animals established by the Society for Neuroscience.

Correspondence should be addressed to Jacqueline Sagen, Department of Anatomy and Cell Biology, University of Illinois at Chicago, 808 South Wood Street, Chicago, IL 60612.

Copyright (c) 1993 Society for Neuroscience $0270-6474 / 93 / 132415-09 \$ 05.00 / 0$
}

Transplants of neural tissues or cells into the CNS are a potential means of achieving sustained delivery of neuroactive substances for the reduction of neurochemical deficits. In particular, this approach may be a means of delivering a continually available and renewable source of pain-reducing substances for the alleviation of chronic pain. It is fairly well established that the activation of noradrenergic or opioid receptors in the spinal cord by direct intrathecal injection of $\alpha$-adrenergic or opioid agonists produces antinociception, and that the coadministration of subeffective doses of these agents may synergize to produce potent analgesia (Yaksh and Reddy, 1981; Wilcox et al., 1987; Drasner and Fields, 1988; Sherman et al., 1988). Work in our laboratory over the past several years has demonstrated that the transplantation of adrenal medullary allografts into the spinal subarachnoid space can reduce both acute and chronic pain (Sagen et al., 1986a, 1990; Hama and Sagen, 1993). This is most likely due to the release of both opioid peptides and catecholamines from the transplanted cells, since the pain reduction can be attenuated by both opioid and $\alpha$-adrenergic antagonists (Sagen and Pappas, 1987). Furthermore, neurochemical assays have demonstrated sustained increased levels of both Met-enkephalin-like immunoreactivity (Sagen and Kemmler, 1989) and catecholamines (Sagen et al., 1991) in the spinal cerebrospinal fluid (CSF) for at least 6 months following transplantation.

Thus, adrenal medullary chromaffin cells may be an ideal source of pain-reducing neuroactive substances for the longterm alleviation of chronic pain. However, the limited availability of human donor tissue for allografts reduces the potential for its large-scale use. Xenogeneic donors may overcome this problem, as they are readily available in large quantities. In particular, large yields of bovine chromaffin cells can be isolated with high viability and purity (Pollard et al., 1984; Ortega et al., 1992a,b). However, the use of widely disparate histoincompatible species could result in potentially severe immunologic responses as well as ultimate graft destruction, despite the relative "immunologic privilege" of the CNS (Mason et al., 1986; Freed et al., 1988; Widner and Brundin, 1988). Recent work in our laboratory has demonstrated that it is possible to prolong bovine chromaffin cell xenografts in the rat CNS using shortterm immunosuppression with cyclosporine A (Ortega et al, 1992a,b). However, other laboratories have reported variable survival of xenografts in the CNS, even with immunosuppression (Finsen et al., 1988; Brundin et al., 1989; Decombe et al., 1990). Furthermore, cyclosporine A can be toxic, with potentially serious complications including hepatotoxicity and neph- 
rotoxicity, as well as tumorigenicity (Harwood and Cook, 1985; Whiting et al., 1985).

Another approach toward overcoming the difficulties of xenotransplantation is the use of permselective membranes to isolate transplanted cells from the surrounding host. These membranes block immune cells, antibodies, and lytic factors of the complement from the transplanted cells, while allowing twoway diffusion of neuroactive substances and growth factors (Aebischer et al., 1988). This approach has been used successfully in the transplantation of dopaminergic tumor cell lines for the alleviation of behavioral deficits in Parkinson's disease models (Aebischer et al., 1991a; Winn et al., 1991). In addition, microencapsulated bovine chromaffin cells survive intracerebral transplantation and can also reduce rotational asymmetry in lesioned rats (Aebischer et al., 1991c). The aim of the present study was to determine whether encapsulated bovine chromaffin cells can provide a long-term source of neuroactive substances in the spinal subarachnoid space for the reduction of pain.

A preliminary report of these findings has been presented previously (Wang et al., 1991).

\section{Materials and Methods}

Encapsulation procedures. Bovine adrenal glands were obtained from a local slaughterhouse, and chromaffin cells were isolated from whole adrenal glands according to methods previously described (Ortega et al., 1992a,b). Following perfusion and digestion with a $0.1 \%$ collagenase solution, the cell population was purified on a Percoll gradient and plated overnight in Dulbecco's modified Eagle's medium:F12 (1:1, containing $5 \%$ fetal bovine serum and antibiotics, $37^{\circ} \mathrm{C}, 5 \% \mathrm{CO}_{2}$ ). For encapsulation, the cells were harvested by aspiration followed by centrifugation at $800 \times g$. Trypan blue exclusion placed the viability of the resulting cell suspension at greater than $95 \%$. Chromaffin cells were suspended in culture media and subsequently loaded into sterile, prespun hollow fibers $(0.6 \mathrm{~mm}$ i.d., $0.75 \mathrm{~mm}$ o.d., $12.0-15.0 \mathrm{~mm}$ long). The hollow fibers consisted of polyacrylonitrile vinyl chloride (PAN-PVC) containing acrylamide 2-methylpropane sulfonate (Polysciences Inc.) and were fabricated by phase inversion from a $15 \%$ solution of PAN-PVC in dimethyl sulfoxide using a dry-jet wet spinning technique (Aebischer et al., 1991b). Cells were loaded via a 24 gauge needle connected to one end of the fiber and pressure injected until extruded through the open end. Capsules were closed by annealing with a heated forceps. Fibers contained approximate chromaffin cell concentrations ranging from 2.0 to $6.0 \times 10^{6} \mathrm{cells} / \mathrm{ml}$, which were estimated from cell density of extruded cells at loading. Since the fibers are hand cut, there is some variability in capsule length and cell numbers, but all capsules were pretested in vitro for catecholamine and opioid peptide release prior to transplantation (see below for details). Capsules prepared without cells served as controls.

Implantation procedures. Male Sprague-Dawley derived rats (Sasco) weighing 325-350 gm were anesthetized (Nembutal, $30 \mathrm{mg} / \mathrm{kg}$, i.p.), and an area of the back overlying the lumbar spine was prepared for aseptic surgery. Following a laminectomy to expose a $3.0-4.0 \mathrm{~mm}$ segment of the lumbar enlargement, a small slit was made in the dura near the midline of the spinal cord. Under a dissecting microscope, one end of either a cell-loaded or empty capsule was placed through the slit and carefully threaded under the dura in the subarachnoid space until the other end was completely under the dura. Following implantation of the capsules, the muscle was sutured, and the skin was closed with wound clips. Animals exhibiting motor abnormalities resulting from surgical procedures (three animals, or $6.3 \%$ ) were killed. The remaining animals were returned to the cages and given food and water ad libitum. Two weeks were allowed for recovery from surgical procedures before commencement of behavioral studies.

Nociceptive testing. Nociceptive thresholds were determined using standard acute analgesiometric tests. The tail flick response (D'Amour and Smith, 1941) was elicited by exposing the blackened dorsal surface of the rat's tail to a focused high-intensity beam of light. The latency between the onset of the light stimulus and the tail flick response was measured at three points on the tail, the average of which was defined as the tail flick latency. The stimulus was terminated at $14 \mathrm{sec}$ in the absence of a response to prevent tissue damage. Since it has recently been suggested that tail temperature can affect tail flick latencies in a negatively correlated fashion (Berge et al., 1988; Han and Ren, 1991), tail skin temperatures were also determined in some cases using an infrared thermometer (Kent Scientific). To determine changes in response to noxious mechanical stimuli, the paw pinch response was elicited using commercially available apparatus (Ugo-Basile) that applies pressure at a constant rate of $64 \mathrm{gm} / \mathrm{sec}$. The force was applied to the ventral surface of both paws sequentially until the animal reacted with a withdrawal response, the average value defined as the paw pinch threshold. The apparatus automatically terminated at a scale reading of 25. Finally, for a more integrated response involving higher centers, the hot plate test (Woolfe and MacDonald, 1944) was used by placing the rat on a $55^{\circ} \mathrm{C}$ copper plate enclosed in a Plexiglas cylinder. The interval between placement on the plate and the response of either licking the hindpaws or jumping off the plate was defined as the hot plate latency. In the absence of a response, the animal was removed after $40 \mathrm{sec}$ and assigned a hot plate latency of 40 .

Nociceptive thresholds were determined before and following injections of low doses of nicotine, since previous studies in our laboratory have shown that this stimulates release of neuroactive substances from the transplanted cells and results in potent antinociception as assessed by acute analgesiometric tests (Sagen et al., 1986a,b, 1991; Sagen and Kemmler, 1989). Following determination of baseline nociceptive responses, animals with chromaffin cell-loaded or empty capsules were injected with nicotine $(0.1 \mathrm{mg} / \mathrm{kg}$, s.c.), and nociceptive responses were again assessed at 2,15 , and $30 \mathrm{~min}$ following the injection. Previous findings have shown that this low dose of nicotine produces potent antinociception in animals with adrenal medullary, but not control, transplants (Sagen et al., 1986a). This dose is approximately equivalent to that ingested in 2-10 cigarettes in humans, depending on brand and body weight. Animals were tested at several intervals following transplantation $(2,4,8$, and 12 weeks) in order to assess the long-term effectiveness of transplanted encapsulated chromaffin cells.

To determine whether response to nicotine was dose related, doseresponse curves were generated $(0.05,0.1$, and $0.2 \mathrm{mg} / \mathrm{kg}$, s.c.) in some animals at weekly intervals between the sixth and eighth week following transplantation, on a counterbalanced dose regimen such that one-third of the animals received each of the doses on each test day, and all animals eventually received all three doses. In addition, to assess the contribution of opioid peptides and catecholamines to the antinociception, some animals were pretreated with either the opiate antagonist naloxone $(\mathrm{HCl}, 2.0 \mathrm{mg} / \mathrm{kg}$, s.c.), the $\alpha$-adrenergic antagonist phentolamine (mesylate, $12.0 \mathrm{mg} / \mathrm{kg}$, s.c.), or saline vehicle $10 \mathrm{~min}$ before nicotine injection, on a similar rotating schedule 6-8 weeks following transplantation.

Neurochemical assays. In order to assay the ability of encapsulated bovine chromaffin cells to sustain release of pain-reducing neuroactive substances, release of both catecholamines and opioid peptides was determined before and after transplantation. Following termination of behavioral testing 12 weeks after transplantation, capsules were removed from some animals following cervical dislocation, and recultured in medium. After $2 \mathrm{~d}$ in culture, individual capsules were placed in 500 $\mu \mathrm{l}$ of Hank's buffered saline $\left(\mathrm{pH} 7.4,37^{\circ} \mathrm{C}\right)$ and $15 \mathrm{~min}$ basal release samples were collected. This was followed by $15 \mathrm{~min}$ stimulations with $60 \mu \mathrm{M}$ nicotine. The samples were divided in half into two tubes containing either antioxidants for catecholamine assays $(4.0 \mathrm{mg} / \mathrm{ml} \mathrm{EDTA}$, $0.5 \mathrm{mg} / \mathrm{ml}$ sodium metabisulfite, $2.5 \mathrm{mg} / \mathrm{ml}$ L-cysteine) or BSA $(1.0 \mathrm{mg} /$ $\mathrm{ml})$ and bacitracin $(5 \mu \mathrm{g} / \mathrm{ml})$ for Met-enkephalin assays, to minimize nonspecific peptide binding and inhibit peptidases, respectively. The samples were lyophilized and frozen at $-30^{\circ} \mathrm{C}$ until assayed. Results of these assays were compared with release from the same capsules prior to transplantation. It is important to note that the in vitro determinations may not indicate the absolute amount of catecholamines and Metenkephalin released from the capsules in vivo, particularly following nicotinic stimulation, since in vivo nicotine concentrations near the capsules following systemic injection are unknown. However, the purpose of these in vitro analyses was to determine continued cell viability and pharmacologic responsiveness of encapsulated chromaffin cells following transplantation.

For determination of catecholamine release, the samples were resuspended in $0.4 \mathrm{~m}$ perchloric acid and extracted with alumina as described previously (Sagen et al., 1991). Catecholamines were quantitated using reverse phase high-performance liquid chromatography (HPLC) with electrochemical detection. The HPLC mobile phase was $0.07 \mathrm{M} \mathrm{Na}$ $\mathrm{H}_{2} \mathrm{PO}_{4}, 0.2 \mathrm{~mm}$ octyl sodium sulfate, $0.1 \mathrm{mM}$ EDTA, and $8 \%$ methanol, 
and the flow rate over a Waters Resolve $\mathrm{C}_{18} \mu$ bondapak column was set at $1.0 \mathrm{ml} / \mathrm{min}$. The electrochemical detector was set at $+0.6 \mathrm{mV}$ vcrsus an $\mathrm{Ag}-\mathrm{AgCl}$ reference electrode. Catecholamine concentrations in the samples were calculated from relative peak areas corrected for recovery of authentic amines (which was $80-90 \%$ ) using a Waters Baseline 810 system. The lower detection limit of the assay was approximately 20 pg (per $100 \mu \mathrm{l}$ sample).

Met-enkephalin levels were determined by radioimmunoassay using commercially available $I^{125}$-labeled Met-enkephalin and Met-enkephalin antisera (Incstar). This antibody has been shown to cross-react $2.8 \%$ with Leu-enkephalin, $0.1 \%$ with $\alpha$-endorphin, and $<0.002 \%$ with substance $\mathrm{P}, \beta$-endorphin, dynorphin ${ }_{1-13}$, and $\alpha$-neoendorphin. Prior to assay, samples were reconstituted in $0.2 \mathrm{~N} \mathrm{HCl}$ and loaded on Sep-Pak preparatory cartridges (Waters) to remove salts using a modification of Bhathena et al. (1989). Peptides were eluted from the columns with $60 \%$ acetonitrile in $0.1 \%$ trifluoracetic acid, lyophilized, and reconstituted in assay buffer. The samples were incubated overnight in equal volumes of tracer (10,000 counts per tube) and antibody (1:6000 final dilution). Serially diluted Met-enkephalin standards (Bachem) were used for generation of the standard curve. The reaction was stopped using IgGsorb (Enzyme Center, diluted 1:40), and the bound fraction was pelleted for counting using a Micromedic Systems gamma counter. The recovery of authentic Met-enkephalin was $95-100 \%$, and the sensitivity limit of this assay was determined to be $0.5 \mathrm{pg}$ of Met-enkephalin (per $100 \mu$ l sample).

Immunocytochemistry. To assess chromaffin cell viability and morphology following transplantation in polymer capsules, some capsules were removed following cervical dislocation after termination of behavioral studies (12 weeks after transplantation) and immersion fixed (4\% paraformaldehyde in $0.1 \mathrm{~m}$ phosphate buffer). The ends of the capsules were opened and the capsules were infiltrated with $5.0 \%$ gelatin in Tris-buffered saline. Following infiltration, the capsules were frozen, and $20 \mu \mathrm{m}$ sections cut on a Hacker-Bright cryostat. The sections were mounted on 3-aminopropyltriethoxy-silane (Sigma) coated slides, and stained immunocytochemically with a tyrosine hydroxylase antibody (Incstar, diluted 1:500) and a rhodamine-linked secondary antibody. Control sections were incubated in preimmune serum instead of primary antibody. Sections were coverslipped in Fluoromount and examined in a Zeiss Axiophot epiffuorescence microscope.

Statistical analysis. Statistical analysis of behavioral tests was done using two-way analysis of variance and the Newman-Keuls test for multiple post hoc comparisons (Keppel, 1973). The paired $t$ test was used to compare neurochemical release before and after transplantation.

\section{Results}

\section{Effects on pain sensitivity}

The effects of chromaffin cell loaded and control capsules on acute pain sensitivity as assessed by the tail flick, paw pinch, and hot plate tests are shown in Figure 1. The data shown were taken from animals 8 weeks following capsule implantation. Neither control nor chromaffin cell-loaded capsules altered baseline nociceptive thresholds from pretransplant levels (not shown). However, following injection of a low dose of nicotine $(0.1 \mathrm{mg} / \mathrm{kg}, \mathrm{s.c}$.), potent analgesia was induced in animals with chromaffin cell-loaded, but not control, capsule implants. Pain thresholds were significantly increased as assessed by the tail flick (Fig. $1 A ; P<0.01$ ), paw pinch (Fig $1 B ; P<0.01$ ), and hot plate (Fig. $1 C ; P<0.05$ ) tests. Pain thresholds were increased by 2 min following nicotine injection, and gradually recovered toward baseline by $30 \mathrm{~min}$.

Since tail temperature has been reported to alter response to the tail flick test inversely, tail skin temperatures were also determined. There were no significant differences in tail temperatures of animals with cell-loaded or control implants, either before or after nicotine injections $(P>0.05)$. Furthermore, nicotine generally produced a slight elevation in tail temperature, an effect opposite to what would be predicted with elevated tail flick latencies, arguing against an interference in the antinociceptive response by temperature alterations.
The analgesia induced by transplanted encapsulated chromattin cells could be repeatedly elicited at several intervals throughout the time course of the study (Fig. 2). Elevated pain thresholds following nicotine could be reliably observed by 2 weeks following transplantation in animals with cell-loaded but not control capsules as assessed by the all three tests $(P<0.01)$. The ability to induce analgesia was maintained for at least 3 months posttransplantation $(P<0.01)$, although there appeared to be some slight, but nonsignificant $(P>0.05)$ decrement in analgesic potencies over time.

To characterize further the responsiveness of transplanted chromaffin cells to nicotinic stimulation, antinociceptive responses to several low doses of nicotine were examined in some animals 6-8 weeks following transplantation. Results are illustrated in Figure 3. There was an apparent dose-related increase in antinociceptive potency in animals with bovine chromaffin cell transplants. The dose-response curve was significantly shifted leftward in animals with cell-loaded compared to control capsules $(P<0.01)$ as assessed by all three analgesiometric tests. The lowest dose of nicotine, $0.05 \mathrm{mg} / \mathrm{kg}$, produced a small but statistically significant elevation in paw pinch threshold and hot plate latencies in animals with cell-loaded implants $(P<0.05)$. At the highest dose of nicotine $(0.2 \mathrm{mg} / \mathrm{kg})$, the elevations in tail flick latency, paw pinch threshold, and hot plate latency were approximately $80 \%, 71 \%$, and $49 \%$ of the maximum cutoff levels, respectively. However, at this dose, there was also a small but significant elevation in the pain thresholds of control animals. These results are similar to findings reported previously with unencapsulated transplants (Sagen et al., 1986b).

To assess the possible contribution of either opioid peptides or catecholamines released from the transplanted chromaffin cells to the pain reduction, some animals were tested following pretreatment with either the opiate antagonist naloxone or the $\alpha$-adrenergic antagonist phentolamine. These results are shown in Figure 4 . These pretreatments did not significantly alter baseline pain thresholds on any of the analgesiometric tests $(P>$ 0.05 ), although there may be a small, but nonsignificant, hyperalgesia to the tail flick stimulus. Both naloxone and phentolamine significantly attenuated the analgesia in animals with chromaffin cell implants as assessed by the tail flick and paw pinch tests $(P<0.01)$, but this attenuation was only significant for phentolamine on the hot plate test. Interestingly, in all cases, the antagonists failed to block the antinociception completely, as pain thresholds were still significantly elevated from baseline $(P<0.05)$.

\section{Neurochemical and morphological analysis}

In order to assess chromaffin cell viability and responsiveness after 3 months of transplantation in semipermeable membranes, capsules were removed from the implantation sites and either recultured for neurochemical analysis or prepared for immunohistochemical analysis. The basal release of catecholamines and Met-enkephalin from the same capsules before and 3 months following transplantation is shown in Figure 5. Statistical analysis revealed that there was no significant decrement in either Met-enkephalin or norepinephrine basally released from the encapsulated chromaffin cells after transplantation $(P>0.05)$. However, epinephrine levels were significantly reduced following transplantation $(P<0.01)$. In addition, dopamine release, which was originally low, was barely detectable following transplantation $(P<0.05)$.

In addition to basal release, recultured capsules apparently 

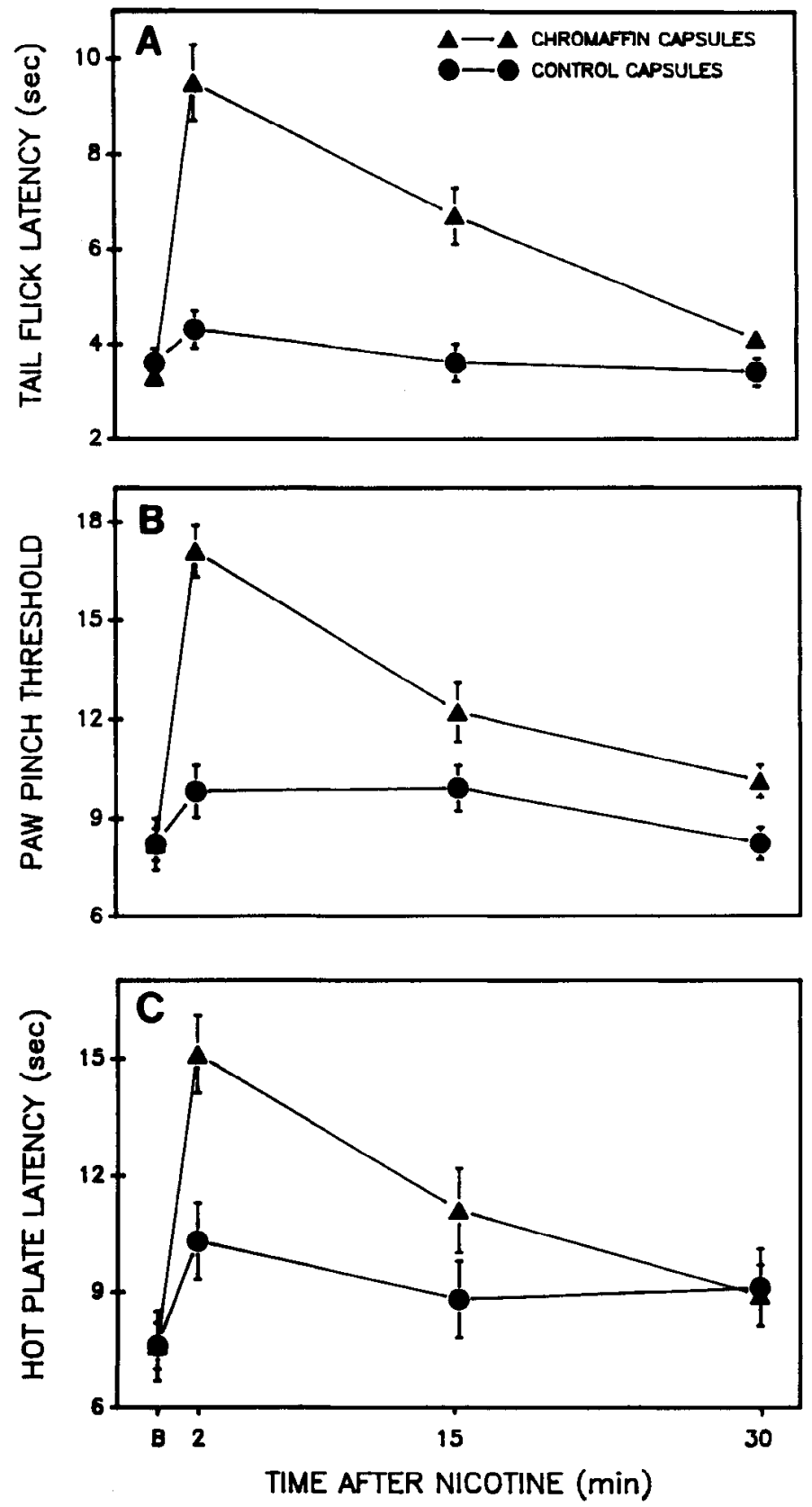

Figure 1. The effect of encapsulated bovine chromaffin cell implants on pain sensitivity. The ordinate is the threshold for response to noxious stimuli as measured by the tail flick test $(A)$, paw pinch test $(B)$, and hot plate test $(C) 8$ weeks following transplantation into the subarachnoid space of the spinal cord. Each point represents the mean \pm SEM for chromaffin cell-loaded capsules (triangles; $n=29$ ) or empty capsules (circles; $\mathbf{n}=16$ ). The abscissa is the time course of responses to noxious stimuli before (labeled $B$ ) and following nicotine stimulation.

retained their ability to respond to nicotinic stimulation, as shown in Figure 6. Met-enkephalin release increased five to six times following stimulation with nicotine, while norepinephrine release increased nearly 12 -fold. In addition, the release of both epinephrine and dopamine from recultured capsules also increased approximately threefold following nicotinic stimulation.

Interestingly, while there was some variability in the number of cells per fiber as well as in the release of catecholamines and Met-enkephalin, there was no significant correlation between
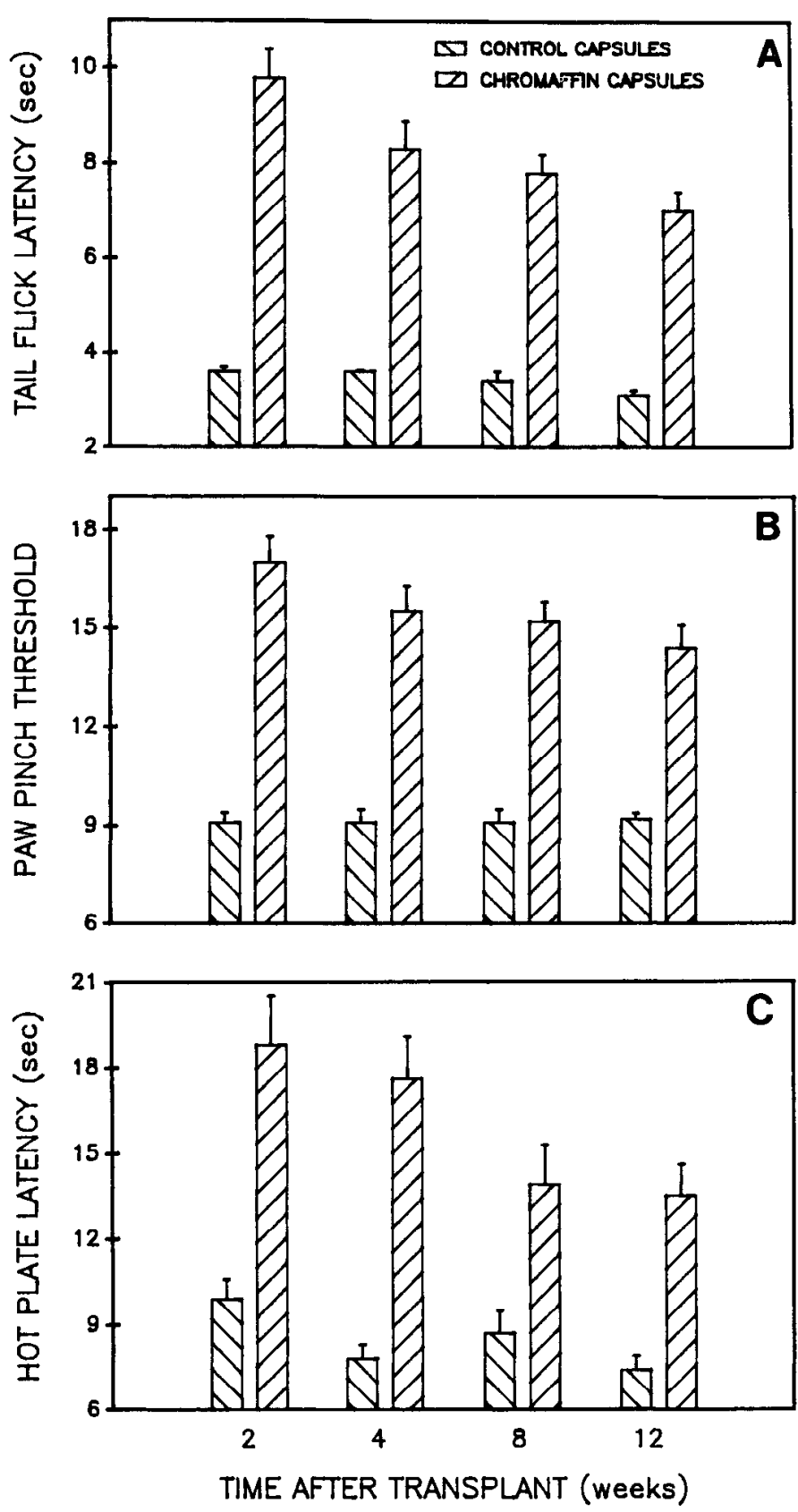

Figure 2. Long-term changes in pain responsiveness in animals with encapsulated bovine chromaffin cell implants in the spinal subarachnoid space. The ordinate is the threshold for response to noxious stimuli as determined by the tail flick test $(A)$, paw pinch test $(B)$, and hot plate test $(C) 2 \mathrm{~min}$ following an injection of nicotine $(0.1 \mathrm{mg} / \mathrm{kg}, \mathrm{s.c}$.). The bars represent the mean \pm SEM for each measurement in animals with empty capsules (left diagonal; $n=16$ ) or bovine chromaffin cell-loaded capsules (right diagonal; $n=29$ ). The abscissa is weeks after capsule implantation.

the level of these agents and analgesic potency. This may be because all of the capsules contained quantities of these agents within an appropriate range to reduce nociception, while masking subtle differences using these analgesiometric testing conditions.

Figure 7 shows the morphological appearance of encapsulated bovine chromaffin cells after 3 months in the spinal subarachnoid space. The cells are readily identified by immunofluorescence with a tyrosine hydroxlase antibody. Typically, small clus- 

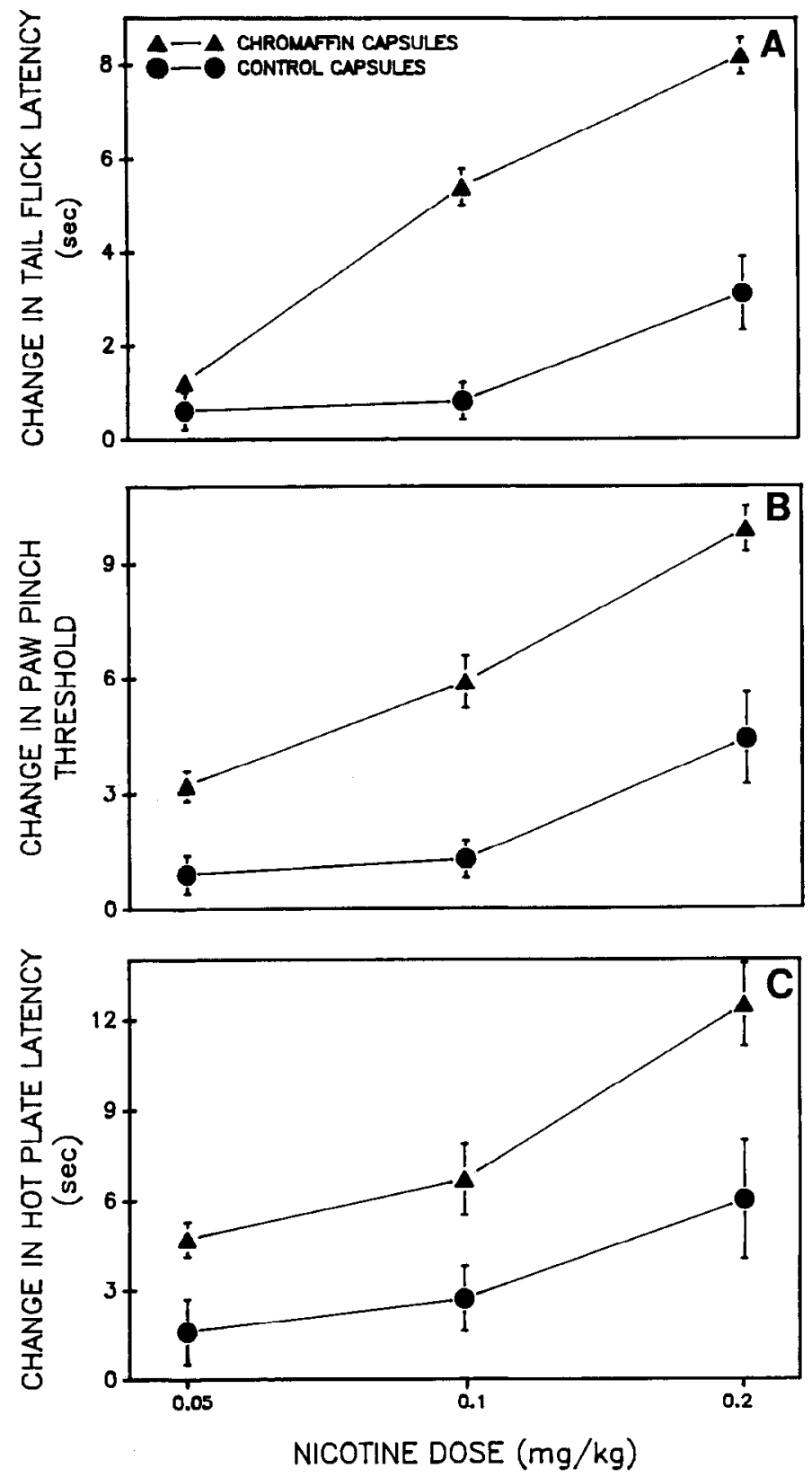

Figure 3. Dose-response relationships for the effect of nicotine on pain sensitivity in animals with encapsulated bovine chromaffin cell implants. The ordinate is changes in nociceptive threshold for the tail flick test $(A)$, paw pinch test $(B)$, and hot plate test $(C)$. Values were obtained by subtracting the prenicotine response latencies from the latencies determined 2 min following nicotine injections. Each point represents the mean \pm SEM for chromaffin cell-loaded capsules (triangles; $n=13$ ) or empty capsules (circles; $n=7)$. The abscissa is nicotine dose $(\mathrm{mg} / \mathrm{kg}$, s.c.) plotted on a logarithmic scale.

ters of chromaffin cells can be found distributed throughout the capsule, particularly near the periphery. The chromaffin cells apparently remain healthy, and generally retain a cuboidal morphology similar to in situ chromaffin cells, without evidence of process formation.

\section{Discussion}

Results of this study indicate that an immunoisolation approach can prevent rejection of xenogeneic grafts in the CNS, while preserving cell viability and pharmacologic effectiveness. One
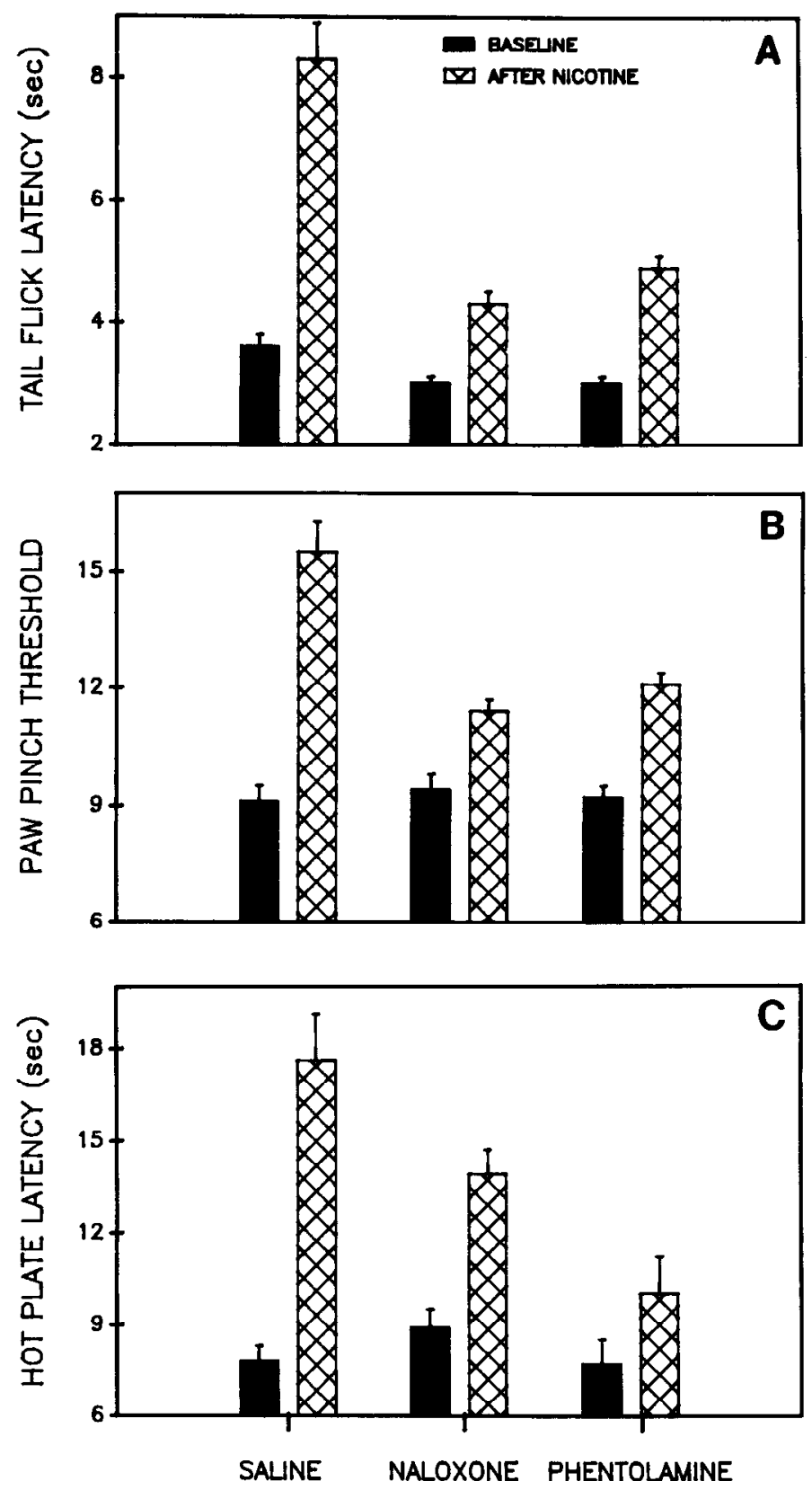

Figure 4. Effect of antagonists on the analgesia induced by nicotine in animals with encapsulated bovine chromaffin cell implants in the spinal subarachnoid space. The ordinate is the threshold for response to noxious stimuli as determined by the tail flick test $(A)$, paw pinch test $(B)$, and hot plate test $(C)$. Each bar represents the mean $\pm \operatorname{SEM}(n=16)$. The solid bars are pain thresholds $10 \mathrm{~min}$ following pretreatment with either saline, naloxone $(\mathrm{HCl}, 2.0 \mathrm{mg} / \mathrm{kg}$, s.c.) or phentolamine (mesylate, $12.0 \mathrm{mg} / \mathrm{kg}$, s.c.). The preinjection values are not shown, since the antagonists did not alter these response latencies. The cross-hatched bars are pain thresholds following nicotine injections $(0.1 \mathrm{mg} / \mathrm{kg}, \mathbf{s . c}$.) given $10 \mathrm{~min}$ following pretreatment with the antagonists.

of the major hurdles in transplantation technology has been the prevention of graft rejection. Even in the CNS, which has classically been considered to be "immunologically privileged" (Medawar, 1948; Barker and Billingham, 1977), the long-term survival of foreign tissue in the CNS appears limited, and xenografts as well as allografts may ultimately be rejected (Freed et al., 1988; Widner and Brundin, 1988). In particular, findings 
Figure 5. Basal release of neuroactive substances from encapsulated bovine chromaffin cells in vitro. The left ordinate is the mean basal levels of catecholamines, and the right ordinate, the mean basal levels of Met-enkephalin released from individual bovine chromaffin cell-loaded capsules. Bars represent the mean \pm SEM prior to implantation (cross-hatched bars) and recultured following removal from the spinal subarachnoid space 3 months after implantation (solid bars), $n=14$. $N E$, norepinephrine; $E P I$, epinephrine; $D A$, dopamine; $M E T$, Met-enkephalin.

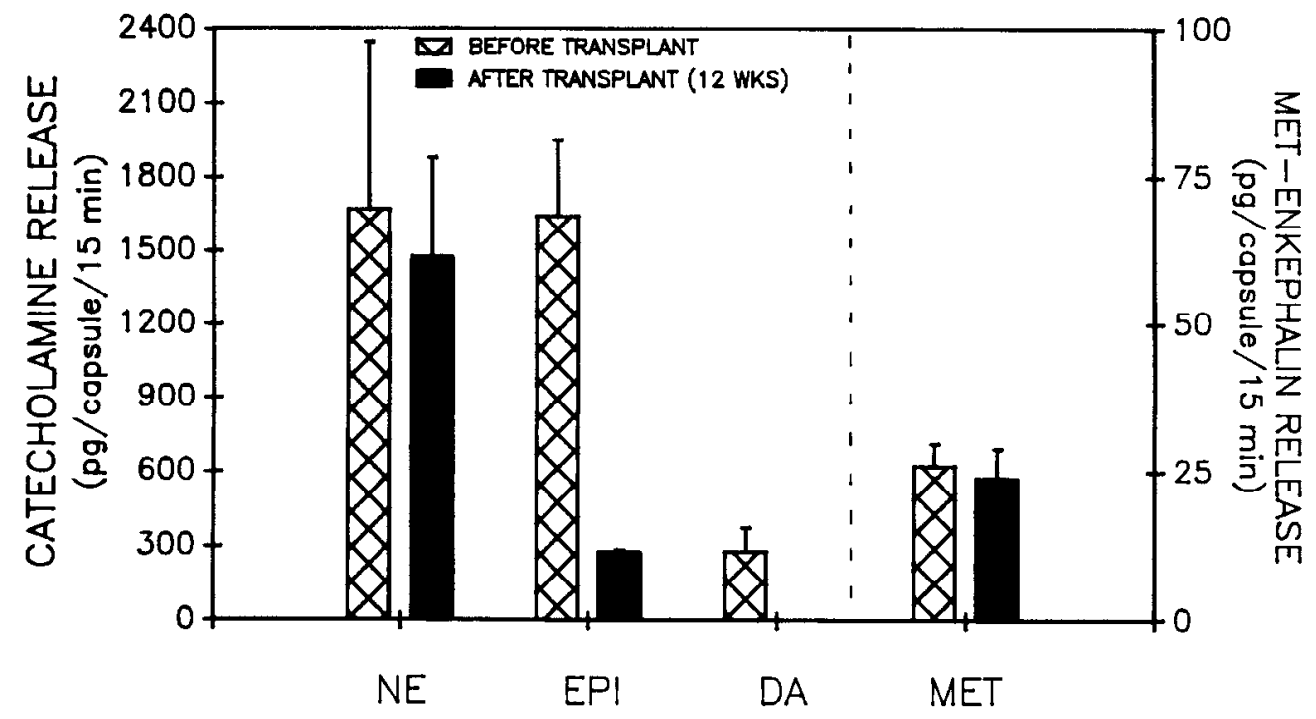

on the survival of CNS xenografts have been quite variable, ranging from successful transplantation and survival to complete rejection (Bjorklund et al., 1982; Mason et al., 1986). This is unfortunate as xenogeneic donors are a potentially rich source of graft material, and would overcome many of the difficulties associated with limited supplies of human tissue.

With the introduction of the immunosuppressant cyclosporine A, organ transplantation has been revolutionized and this therapy has now been widely used for the prevention of graft rejection in humans (White and Calne, 1982; Thomson, 1983; Morris, 1984). However, while recent work in our and other laboratories has suggested that cyclosporine A treatment, possibly even on a short-term basis, can significantly improve xenograft survival in the CNS (Finscn et al., 1988; Ortega et al., 1992a), others have found that, even with immunosuppression, the survival of xenografts is variable, and may be rejected when treatment is terminated (Brundin et al., 1989). Furthermore, the potential toxicity of cyclosporine A may limit its long-term usefulness.

An advantage of the encapsulation approach is that permselective membranes can protect xenogeneic cells from rejection, while allowing for the diffusion of neuroactive substances from the transplanted cells to host CNS receptors. This approach is particularly advantageous for transplantation in the spinal subarachnoid space, where the administration of opiates and other agents via intrathecally implanted pumps has been successfully used in the management of pain. However, intrathecal drug administration is not optimal for producing continuous alleviation of pain in chronic conditions, and can be inconvenient as well as introduce problems such as malfunction and infection. A significant advantage of transplantation, if successful, is the ability to provide a renewable source of painreducing neuroactive substances on a long-term or permanent basis.

The results of this study demonstrate that polymer-encapsulated bovine chromaffin cells can survive for extended periods when transplanted into the rat spinal subarachnoid space. As revealed by neurochemical and morphological studies, the chromaffin cells apparently remain healthy and continue to produce catecholamines and opioid peptides. In addition, pharmacologic integrity is retained, as indicated by their continued ability to respond to nicotinic stimulation.

Most importantly, the transplanted encapsulated chromaffin cells can reduce pain, and this effect is maintained without dec-
Figure 6. Basal and nicotine-stimulated release of neuroactive substances from encapsulated bovine chromaffin cells recultured following removal from the spinal subarachnoid space 3 months after implantation. The left ordinate is the mean catecholamine release, and the right ordinate is the mean Met-enkephalin release from individual bovine chromaffin cell-loaded capsules. Bars represent the mean $\pm S E M$ release basally (left diagonal) and with nicotine stimulation (right diagonal; $60 \mu \mathrm{M}$ ), $n$ $=14$. $N E$, norepinephrine; $E P I$, epinephrine; $D A$, dopamine; $M e t$, Met-enkephalin.

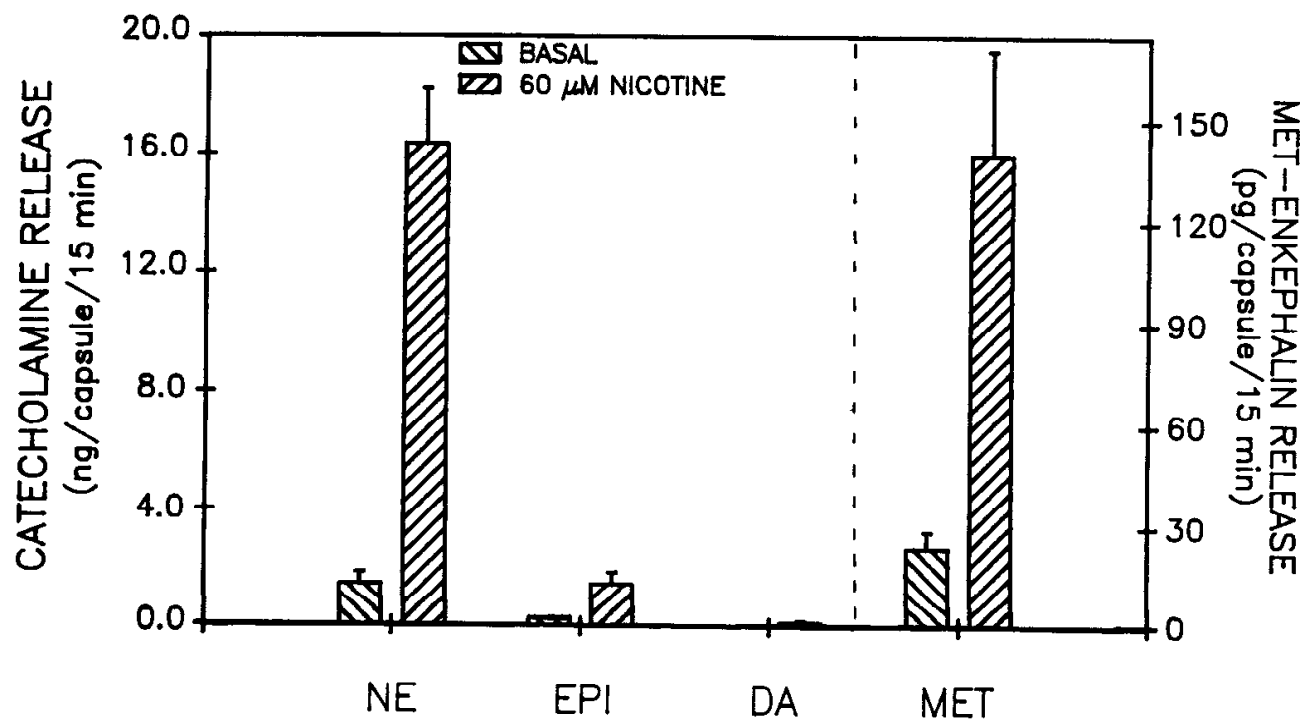




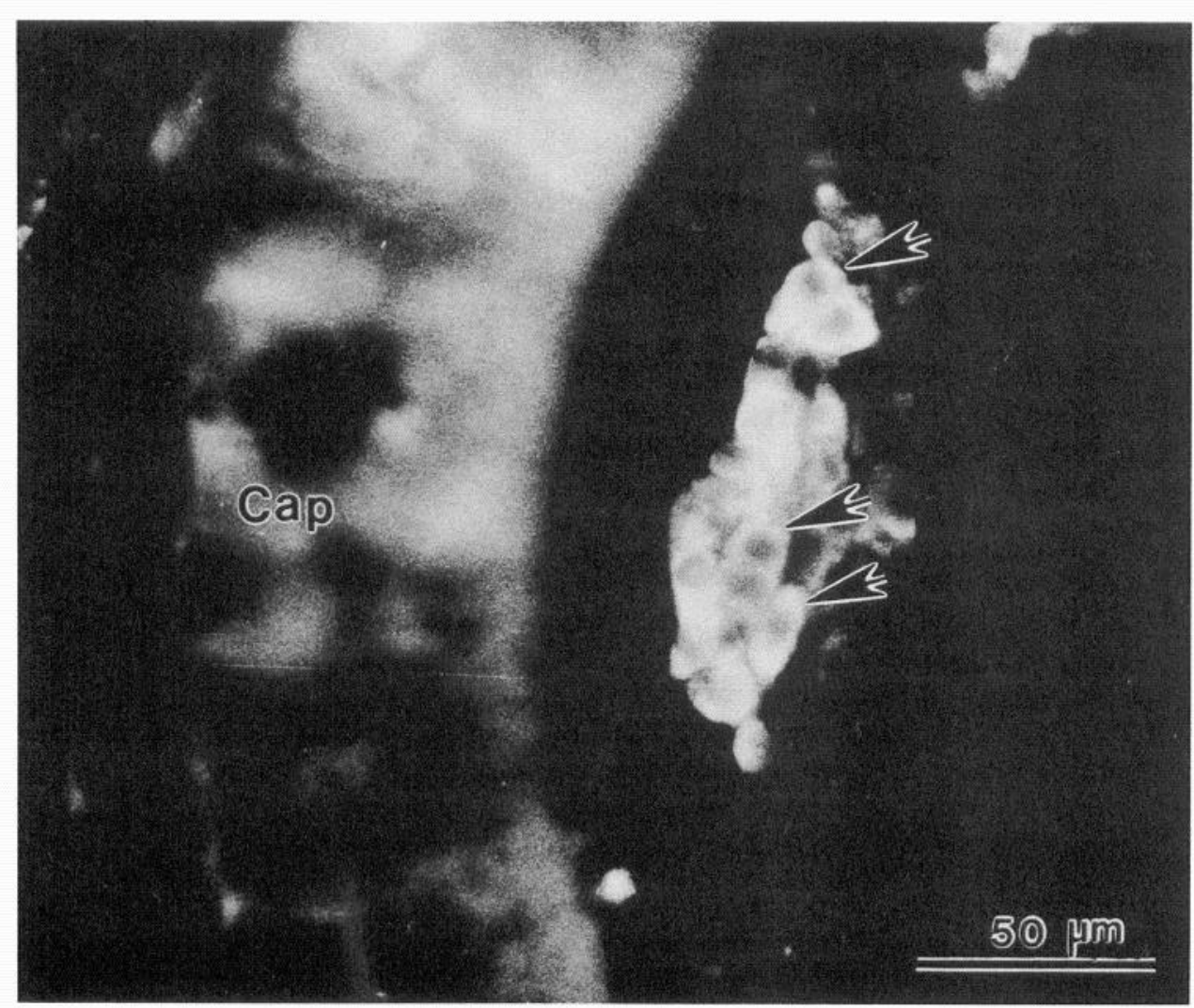

Figure 7. Appearance of encapsulated bovine chromaffin cells 3 months following implantation into the spinal subarachnoid space. Bovine chromaffin cells are immunocytochemically stained with a tyrosine hydroxylase antibody. The cells (arrows) tend to form small clusters near the capsule (Cap) wall. rement for at least 3 months posttransplantation. The potency of this analgesic response is similar to findings in previous studies using adrenal medullary allografts and unencapsulated xenografts in immunosuppressed animals (Sagen et al., 1986a,b; Sagen and Pappas, 1987). The mechanism of induction of analgesia by transplanted chromaffin cells is unclear, although it is likely that both catecholamines and opioid peptides released from the cells are involved, since the response is attenuated by either the opiate antagonist naloxone or the $\alpha$-adrenergic antagonist phentolamine. Both opiates and $\alpha$-adrenergic agonists have been well documented in their ability to reduce pain when administered intrathecally (Yaksh et al., 1977; Reddy et al., 1980; Yaksh and Reddy, 1981; Hylden and Wilcox, 1983; Kuraishi et al., 1985). However, since the analgesia induced by chromaffin cell transplants was not completely blocked by either the opiate or adrenergic antagonist, this response cannot be completely accounted for by either opioids or catecholamines alone. It is likely that both agents are necessary to elicit the observed antinociceptive activity. In addition, chromaffin cells produce other agents, including neuropeptides such as neuropeptide $Y$, vasoactive intestinal polypeptide, neurotensin, and somatostatin (Kondo, 1985; Gaumann and Yaksh, 1988; Bommer and Herz, 1989), many of which have been implicated in spinal nociceptive modulation (Recht and Abrams, 1986; Cridland and Henry, 1988; Spampinato et al., 1988; Hua et al., 1991). Some of these agents could also participate in the alterations in pain sensitivity produced by chromaffin cell transplants.

Using acute analgesiometric tests, the results of this study suggest that the transplanted cells must be stimulated by nicotine in order to induce their acute antinociceptive effects. This is supported by dose-response studies that indicate a significant dose dependency to nicotine. However, recent studies in our laboratory suggest that basal levels of neuroactive substances from adrenal medullary allografts are sufficient to reduce pain in two chronic pain models in the absence of nicotine (Sagen et al., 1990; Hama and Sagen, 1993). Thus, it is possible that lowintensity chronic pain may be alleviated by basal release of neuroactive substances from chromaffin cell transplants without nicotinic stimulation, while episodes of higher-intensity acute pain may require increased released by nicotine.

It is apparent from the neurochemical assays that the levels of Met-enkephalin released from the encapsulated cells are low compared to the concentrations generally used to produce analgesia with direct intrathecal injections (Yaksh et al., 1977; Larson et al., 1980). However, the continual output of substances from transplanted cells may allow for some buildup in local concentrations in the spinal cord. Furthermore, although only Met-enkephalin levels were determined in the present study, the adrenal medulla produces numerous small-, intermediate-, and large-sized opioid peptides in addition to Met-enkephalin (Stern et al., 1980; Boarder et al., 1982; Liston et al., 1984; Birch and Christie, 1986). Several of these, including Met-enkephalin$\mathrm{Arg}^{6}-\mathrm{Phe}^{7}$, Met-enkephalin-Arg ${ }^{6}-\mathrm{Gly}^{7}-\mathrm{Leu}^{8}$, and BAM-18, have significant antinociceptive activity (Inturrisi et al., 1980; Iadorola et al., 1986; Stevens et al., 1988). The observed decreases in pain sensitivity by chromaffin cell implants may be due to the release of several opioid peptides products in the spinal CSF. In addition, since chromaffin cells synthesize other pharmacologically active substances, it is likely that the analgesia is due to a combination of these agents. In particular, opioids and catecholamines appear to be an especially potent combination, as the coadministration of subeffective doses of opioid and $\alpha$-adrenergic agonists synergizes to produce marked antinociception 
(Wilcox et al., 1987; Drasner and Fields, 1988; Sherman et al., 1988). Thus, chromaffin cells may produce a fortuitous combination of neuroactive substances for the alleviation of pain.

In addition, although chromaffin cells evidently continually release neuroactive substances both in capsules (present study) and in solid tissue allografts (Sagen and Kemmler, 1989; Sagen et al., 1991), there does not appear to be a significant reduction in analgesic potency over time as a result of this constant exposure. In other studies, there is also no apparent decrement in chronic pain reduction by adrenal medullary allografts (Sagen et al., 1990; Hama and Sagen, 1993). It is possible that the low levels of opioid peptides and catecholamines released basally by the cells synergize to produce pain reduction without development of appreciable tolerance. Similar findings have been suggested by the coadministration of opioids and $\alpha$-adrenergic agonists intrathecally (Yaksh and Reddy, 1981).

Although chromaffin cells normally release several catecholamines, it is likely that norepinephrine is primarily involved in the pain reduction, since it is released in greatest quantities after transplantation. The reduction in epinephrine release from isolated chromaffin cells is not surprising, and is most likely due to the removal of the steroid-secreting adrenal cortex, leading to a decreased conversion of norepinephrine to epinephrine by phenylethanolamine- $N$-methyltransferase (Wurtman et al., 1972). However, the reduction in dopamine release following transplantation is somewhat surprising, as removal of the adrenal cortex reportedly increases dopamine levels in chromaffin cells, and has been an impetus in the use of adrenal medullary tissue as a source for dopamine replacement in Parkinson's disease (for review, see Gash and Sladek, 1988). Furthermore, dopamine levels have been shown to increase in encapsulated bovine chromaffin cells in vitro (Aebischer et al., 1991c). It is likely that the CNS environment is not precisely mimicked by tissue culture conditions, and that subtle differences in the neurochemical milieu may significantly influence the metabolic activity of the transplanted cells. In support of this, other studies have also failed to detect appreciably release of dopamine from chromaffin cells transplanted to the CNS (Becker and Freed, 1988; Sagen et al., 1991).

In summary, the results of this study demonstrate that xenografts can survive transplantation and continue to function in the CNS when immunologically protected by polymer encapsulation. This approach, by overcoming one of the scrious difficulties in transplantation, may offer new potential for neural implants in the management of clinical problems, including intractable pain.

\section{References}

Aebischer P, Winn SR, Galletti PM (1988) Transplantation of neural tissue in polymer capsules. Brain Res 448:364-368.

Aebischer P, Wahlberg L, Tresco PA, Winn SR (1991a) Macroencapsulation of dopamine secreting cells by co-extrusion with an organic polymer solution. Biomaterials 12:50-56.

Aebischer P, Tresco PA, Winn SR, Greene LA, Jaeger CB (199lb) Long term cross-species brain transplantation of a polymer encapsulated dopamine-secreting cell-line. Exp Neurol 1 1 1:269-275.

Aebischer P, Tresco PA, Sagen J, Winn S (1991c) Transplantation of microencapsulated bovine chromaffin cells reduces lesion-induced rotational asymmetry in rats. Brain Res 560:43-49.

Barker CF, Billingham RE (1977) Immunologically privileged sites. Adv Immunol 25:1-54.

Becker JB, Freed WJ (1988) Neurochemical correlates of behavioral changes following intraventricular adrenal medulla grafts: intraventricular microdialysis in freely moving rats. Prog Brain Res 78:527533.
Berge O-G, Garcia-Cabrera I, Hole K (1988) Response latencies in tail-flick test depend on tail skin temperature. Neurosci Lett 86:284 288.

Bhathena SJ, Smith PM, Kennedy BW, Voyles NR, Recant L (1989) Simultaneous extraction of $\beta$-endorphin and Leu- and Met-enkephalins from human and rat plasma. Life Sci 45:901-906.

Birch NP, Christie DL (1986) Characterization of the molecular forms of proenkephalin in bovine adrenal medulla and rat adrenal, brain, and spinal cord with a site-directed antiserum. J Biol Chem 261: 12213-12221.

Bjorklund A, Stenevi U, Dunnett SB, Gage FH (1982) Cross-species grafting in a rat model of Parkinson's disease. Nature 298:652-654.

Boarder MR, Lockfeld AJ, Barchas JD (1982) Met-enkephalin [Arg ${ }^{6}$, $\left.\mathrm{Phe}^{\prime}\right]$ immunoreactivity in bovine caudate and bovine adrenal medulla. J Neurochem 39:149-154.

Bommer N, Herz A (1989) Neuropeptides and other secretagogues in bovine chromaffin cells: their effect on opioid peptide metabolism. Neuropeptides 13:243-251.

Brundin P, Widner H, Nilsson OG, Strecker RB, Bjorklund A (1989) Intracerebral xenografts of dopamine neurons: the role of immunosuppression and the blood-brain barrier. Exp Brain Res 75:195-207.

Cridland RA, Henry JL (1988) Effects of intrathecal administration of neuropeptides on a spinal nociceptive reflex in the rat: VIP, galanin, CGRP, TRH, somatostatin, and angiotensin II. Neuropeptides 11: 23-32.

D'Amour FE, Smith DL (1941) A method for determining loss of pain sensation. J Pharmacol Exp Ther 72:74-79.

Decombe R, Rivot JP, Aunis D, Abrous N, Paschanski M, Herman JP (1990) Importance of catecholamine release for the functional action of intrastriatal implants of adrenal medullary cells: pharmacological analysis and in vivo electrochemistry. Exp Neurol 107:143-153.

Drasner K, Fields HF (1988) Synergy between the antinociceptive effects of intrathecal clonidine and systemic morphine in the rat. Pain 32:309-312.

Finsen B, Poulson PH, Zimmer J (1988) Xenografting of fetal mouse hippocampal tissue to the brain of adult rats: effects of cyclosporine A treatment. Exp Brain Res 70:117-133.

Freed WJ, Dymecki J, Poltorak M, Rodgers CR (1988) Intraventricular brain allografts and xenografts: studies of survival and rejection with and without systemic sensitization. Prog Brain Res 78:233-241.

Gash DM, Sladek JR Jr, eds (1988) Progress in brain research, Vol 78, Transplantation into the mammalian CNS. Amsterdam: Elsevier.

Gaumann DM, Yaksh TL (1988) Effects of hemorrhage and opiate antagonists on adrenal release of neuropeptides in cats. Peptides 9:393405.

Hama AT, Sagen J (1993) Reduced pain-related behavior by adrenal medullary transplants in rats with experimental painful peripheral neuropathy. Pain, in press.

Han JS, Ren MF (1991) The importance of monitoring tail-skin temperature in measuring tail-flick latency. Pain 46:117.

Harwood CH, Cook CV (1985) Cyclosporine in transplantation. Heart Lung 14:529-540.

Hua X-Y, Boublik JH, Spicer MA, Rivier JE, Brown MR, Yaksh TL (1991) The antinociceptive effects of spinally administered neuropeptide $Y$ in the rat: systematic studies on structure-activity relationship. J Pharmacol Exp Ther 258:243-248.

Hylden JLK, Wilcox GL (1983) Pharmacological characterization of substance $P$-induced nociception in mice: modulation by opioid and noradrenergic agonists at the spinal level. J Pharmacol Exp Ther 226: $398-404$.

Iadorola MJ, Tang J, Costa E, Yang H-YT (1986) Analgesic activity and release of $\left[\mathrm{Met}^{5}\right]$ enkephalin-Arg ${ }^{6}-\mathrm{Gly}^{7}-\mathrm{Leu}^{8}$ from rat spinal cord in vivo. Eur J Pharmacol 121:39-48.

Inturrisi CE, Umans JG, Wolff D, Stern AS, Lewis RV, Stein S, Udenfriend $S$ (1980) Analgesic activity of the naturally occurring heptapeptide [Met] enkephalin-Arg ${ }^{6}-$ Phe $^{7}$. Proc Natl Acad Sci USA 77: 5512-5514.

Keppel G (1973) Design and analysis: a researcher's handbook. Englewood Cliffs, NJ: Prentice-Hall.

Kondo $H$ (1985) Immunohistochemical analysis of the localization of neuropeptides in the adrenal gland. Arch Histol Jpn 48:453-481.

Kuraishi Y, Hirota N, Satoh M, Takagi H (1985) Antinociceptive effects of intrathecal opioids, noradrenaline, and serotonin in rats: mechanical and thermal algesic tests. Brain Res 326:168-171. 
Larson AA, Vaught JL, Takemori AE (1980) The potentiation of spinal analgesia by leucine enkephalin. Eur J Pharmacol 61:381-383.

Liston D, Patey G, Rossier J, Verbanck J, Vanderhaeghen J-J (1984) Processing of proenkephalin is tissue specific. Science 225:734-737.

Mason DW, Charlton HM, Jones AJ, Lavy CBD, Puklavec M, Simmonds SJ (1986) The fate of allogeneic and xenogeneic neuronal tissue transplanted into the third ventricle of rodents. Neuroscience 19:685-694.

Medawar PB (1948) Immunity to homologous grafted skin. III. The fate of skin grafts implanted to the brain, to subcutaneous tissue, and to the anterior eye chamber of the eye. Br J Exp Pathol 29:58-69.

Morris PJ (1984) The impact of cyclosporin A on transplantation. Adv Surg 17:99-127.

Ortega JD, Sagen J, Pappas GD (1992a) Short-term immunosuppression enhances long-term survival of bovine chromaffin cell xenografts in rat CNS. Cell Transplant 1:33-41.

Ortega JD, Sagen J, Pappas GD (1992b) Survival and integration of bovine chromaffin cells transplanted into rat central nervous system without exogenous trophic factors. J Comp Neurol 322:1-12.

Pollard HB, Pazoles C, Creutz CE, Scott JH, Zinder O, Hotchkiss A (1984) An osmotic mechanism for exocytosis from dissociated chromaffin cells. J Biol Chem 259:1114-1121.

Recht LD, Abrams GM (1986) Neuropeptides and their role in nociception and analgesia. Neurol Clin 4:833-852.

Reddy SVR, Maderdrut JL, Yaksh TL (1980) Spinal cord pharmacology of adrenergic agonist-mediated antinociception. J Pharmacol Exp Ther 213:525-533.

Sagen J, Kemmler JE (1989) Increased levels of Met-enkephalin-likeimmunoreactivity in the spinal cord CSF of rats with adrenal medullary transplants. Brain Res 502:1-10.

Sagen J, Pappas GD (1987) Morphological and functional correlates of chromaffin cell transplants in CNS pain modulatory regions. In: Annals of the New York Academy of Science, Vol 495, Cell and tissue transplantation into the adult brain (Azmitia EC, Bjorklund A, eds), pp 306-333. New York: New York Academy of Science.

Sagen J, Pappas GD, Perlow MJ (1986a) Adrenal medullary tissue transplants in the rat spinal cord reduce pain sensitivity. Brain Res 384:189-194.

Sagen J, Pappas GD, Pollard HB (1986b) Analgesia induced by isolated bovine chromaffin cells implanted in rat spinal cord. Proc Natl Acad Sci USA 83:7522-7566.

Sagen J, Wang H, Pappas GD (1990) Adrenal medullary implants in the rat spinal cord reduce nociception in a chronic pain model. Pain 42:69-79.

Sagen J, Kemmler JE, Wang H (1991) Adrenal medullary transplants increase spinal cord cerebrospinal fluid catecholamine levels and reduce pain sensitivity. J Neurochem 56:623-627.
Sherman SE, Loomis CW, Milne B, Cervenko FW (1988) Intrathecal uxymetazoline produces analgesia via spinal $\alpha$-adrenoceptors and potentiates spinal morphine. Eur J Pharmacol 148:371-380.

Spampinato S, Romualdi P, Candeletti S, Cavicchini E, Ferri S (1988) Distinguishable effects of intrathecal dynorphins, somatostatin, neurotensin and s-calcitonin on nociception and motor function in the rat. Pain 35:95-104.

Stern AS, Lewis RV, Kimura S, Rossier J, Stein S, Udenfriend S (1980) Opioid hexapeptides and heptapeptides in adrenal medulla and brain possible implications on the biosynthesis of enkephalins. Arch Biochem Biophys 205:606-613.

Stevens KE, Leslie FM, Evans CJ, Belluzzi JD, Stein L (1988) BAM18: analgesia, hyperalgesia and locomotor effects. Neuropeptides 12 21-27.

Thomson AW (1983) Immunobiology of cyclosporin A: a review. Aust J Exp Biol Med Sci 61:147-172.

Wang H, Tresco PA, Aebischer P, Sagen J (1991) Pain reduction by transplants of polymer encapsulated bovine chromaffin cells in the rat spinal subarachnoid space. Soc Neurosci Abstr 17:235.

White DJG, Calne RY (1982) The use of cyclosporin A immunosuppression in organ grafting. Immunol Rev 65:115-131.

Whiting PH, Thomson AW, Simpson JG (1985) Cyclosporine: toxicity, metabolism, and drug interactions-implications from animal studies. Transplant Proc 27:134-144

Widner H, Brundin P (1988) Immunological aspects of grafting in the mammalian central nervous system. A review and speculative synthesis. Brain Res Rev 13:287-324.

Wilcox GL, Carlsson K, Jochim A, Jurna I (1987) Mutual potentiation of antinociceptive effects of morphine and clonidine on motor and sensory responses in rat spinal cord. Brain Res 405:84-93.

Winn SR, Tresco PA, Zielinski G, Greene LA, Jaeger CB, Aebischer P (1991) Behavioural recovery following intrastriatal implantation of microencapsulated PC12 cells. Exp Neurol 113:322-329.

Woolfe G, MacDonald AD (1944) The evaluation of the analgesic action of pethidine hydrochloride (Demerol). J Pharmacol Exp Ther 80:300-307.

Wurtman RJ, Pohorecky LA, Baliga GS (1972) Adrenocortical control of the biosynthesis of epinephrine and proteins in the adrenal medulla. Pharmacol Rev 24:411-426.

Yaksh TL, Reddy SVR (1981) Studies in the primate on the analgetic effects associated with intrathecal actions of opiates, alpha-adrenergic agonists and baclofen. Anesthesiology 54:451-467.

Yaksh TL, Huang SP, Rudy TA, Frederickson RCA (1977) The direct and specific opiate-like effect of $\mathrm{Met}^{5}$-enkephalin and analogues on the spinal cord. Neuroscience 2:593-596. 